\title{
Pengaruh Emotional Quotient dan Adversity Quotient Terhadap Prestasi Belajar Matematika Peserta didik Kelas XI SMA
}

\author{
Nur Rachmat ${ }^{1, a)}$, Ilham Minggi ${ }^{1, b)}$ dan Bernard ${ }^{1, \mathrm{c})}$ \\ ${ }^{1}$ Jurusan Matematika FMIPA Universitas Negeri Makassar \\ a)nurrachmat309@gmail.com \\ b)ilhamminggi@gmail.com \\ c)bernard@unm.ac.id
}

\begin{abstract}
Abstrak. Penelitian ini bertujuan untuk menganalisis pengaruh langsung dari Emotional Quotient (EQ) dan Adversity Quotient (AQ) terhadap Prestasi Belajar Matematika kelas XI SMA. Pada analisis ini EQ dan AQ merupakan variabel bebas sedangkan Prestasi Belajar Matematika merupakan variabel terikat. Teknik pengambilan sampel pada penelitian ini menggunakan metode cluster proportional random sampling dan jumlah sampel yaitu 158 peserta didik. Teknik pengumpulan data yaitu dengan menggunakan instrumen tes dan non-tes. Adapun instrumen digunakan yaitu (1) angket EQ, (2) angket adversity response profile, dan (3) tes Prestasi Belajar Matematika. Metode analisis data menggunakan teknik analisis regresi linear berganda. Hasil penelitian menunjukkan bahwa: (1) EQ peserta didik berada pada kategori sedang, dan $A Q$ peserta didik berada pada kategori camper, sedangkan Prestasi Belajar Matematika berada pada kategori rendah, (2) EQ memiliki pengaruh terhadap Prestasi Belajar Matematika, dan (3) AQ tidak memiliki pengaruh terhadap Prestasi Belajar Matematika.
\end{abstract}

Kata kunci: emotional quotient, adversity quotient, prestasi belajar matematika

Abstrak. This study aims to analyze the direct effect of Emotional Quotient (EQ) and Adversity Quotient $(A Q)$ on Mathematics Learning Achievement in class XI SMA. In this analysis, EQ and $A Q$ are independent variables while Mathematics Learning Achievement is the dependent variable. The sampling technique in this study used the cluster proportional random sampling method and the number of samples was 158 students. Data collection techniques, namely by using test and non-test instruments. The instruments used were (1) EQ questionnaire, (2) adversity response profile questionnaire, and (3) mathematics learning achievement test. Methods of data analysis using multiple linear regression analysis techniques. The results showed that: (1) students ' $E Q$ was in the medium category, and students' $A Q$ was in the camper category, while Mathematics Learning Achievement was in the low category, (2) $E Q$ had an influence on Mathematics Learning Achievement, and (3) $A Q$ has no influence on Mathematics Learning Achievement.

Keywords: emotional quotient, adversity quotient, mathematics learning achievement

\section{PENDAHULUAN}

Keberhasilan pembelajaran merupakan hal yang sangat diinginkan oleh setiap pendidik. Salah satu bentuk nyata keberhasilan suatu pembelajaran dapat dilihat dari prestasi belajar yang dicapai oleh peserta didik. Melalui prestasi belajar, pendidik dapat melihat sejauh mana pemahaman materi peserta didik setelah materi diajarkan. Hal ini sesuai dengan apa yang dikatakan Chien (Adiputra \& Mujiati, 2017) bahwa prestasi belajar dapat didefinisikan sebagai perolehan pengetahuan atau keterampilan yang dikembangkan oleh materi pelajaran, yang 
biasanya ditunjukkan dengan nilai tes atau nilai numerik yang ditugaskan oleh pendidik. Pernyataan tersebut didukung oleh Akbar \& Hawadi (2004) yang mengatakan bahwa prestasi belajar adalah hasil penilaian pendidik terhadap proses belajar dan hasil belajar peserta didik sesuai dengan tujuan intruksional yang menyangkut isi pelajaran dan perilaku yang diharapkan diperoleh peserta didik.

Pembelajaran matematika mempunyai tujuan yang menjadi patokan tercapainya prestasi belajar matematika peserta didik yang memuaskan. Tujuan pembelajaran menjadi target dalam proses belajar mengajar disekolah agar kegiatan pembelajaran dapat terarah dan memperoleh hasil yang sesuai dengan apa yang diharapkan oleh setiap pendidik. Namun, pada kenyataannya tidak jarang peserta didik mengalami masalah dan kesulitan untuk dapat mencapai tujuan pembelajaran matematika tersebut. Adapun masalah atau kesulitan yang dihadapi oleh peserta didik ketika pembelajaran berlangsung sangat bervariasi. Terdapat peserta didik yang menglami kendala ketika menghadapi suatu permasalahan pembelajaran, tetapi juga terdapat peserta didik yang mampu mengatasi setiap permasalahan pembelajaran yang dihadapinya. Namun, pada dasarnya sebagai pendidik tentunya guru berharap bahwa peserta didik yang mengalami kesulitan agar tidak putus semangat, dan terus berusaha untuk mencari jalan penyelesaian terhadap permasalahan matematika yang dihadapinya. Maka dari itu, agar peserta didik dapat meraih hasil yang maksimal dalam menghadapi suatu permasalahan dalam pembelajaran matematika dibutuhkan ketangguhan dan daya juang yang kuat dari peserta didik. Ketangguhan dan daya juang inilah yang kemudian di konseptualisasikan oleh Stoltz (2000) sebagai kecerdasan ketegaran disebut juga dengan adversity quotient (AQ).

Pada proses pembelajaran di kelas, peserta didik haruslah memiliki daya juang yang tinggi dan tetap gigih dalam menyelesaikan tugas-tugas yang diberikan walaupun menghadapi hambatan ketika mengerjakan tugas-tugas tesebut. Menurut Supardi (2013) AQ inilah yang dapat mendukung daya juang peserta didik dalam menghadapi berbagai kesulitan yang mungkin saja muncul selama proses belajar mengajar yang dialami peserta didik itu sendiri. Hal ini menunjukkan bahwa AQ memiliki dampak terhadap kesuksesan peserta didik dalam meraih prestasi belajar yang memuaskan.

AQ dapat memberikan dampak terhadap meningkatnya prestasi belajar matematika peserta didik. Hal ini sejalan dengan hasil penelitian yang dilakukan oleh Supardi (2013) yang menunjukkan bahwa terdapat pengaruh adversity quotient terhadap prestasi belajar matematika, yang berarti bahwa semakin tinggi tingkat adversity quotient peserta didik, maka semakin tinggi pula prestasi belajar matematikanya, dan sebaliknya, semakin rendah tingkat $A Q$ peserta didik, maka semakin rendah pula prestasi belajar matematikanya. Hal tersebut dapat terjadi karena peserta didik yang memiliki AQ yang tinggi akan mampu mengontrol dirinya agar tidak mudah menyerah ketika menghadapi suatu masalah pada saat pembelajaran berlangsung. Hasil tersebut sejalan dengan hasil penelitian Nurhayati dan Fajrianti (2013) yang menunjukkan bahwa terdapat pengaruh yang signifikan dari $A Q$ terhadap prestasi belajar matematika. Siswa yang memiliki $A Q$ yang tinggi akan mampu menyelesaikan setiap hambatan yang dihadapinya dan meraih prestasi belajarnya termasuk dalam pelajaran matematika. Dari penjabaran dan hasil penelitian dapat disimpulkan bahwa peserta didik memiliki $A Q$ tinggi akan mampu menyelesaikan hambatan dihadapinya dan meraih prestasi dalam belajarnya termasuk dalam pelajaran matematika. adapun hasil penelitian lain yang dilakukan oleh Leonard \& Amanah (2014) menunjukkan bahwa adanya pengaruh yang signifikan antara AQ terhadap prestasi belajar matematika, yang menandakan bahwa semakin baik AQ peserta didik maka semakin baik pula prestasi belajar matematika yang dimilikinya. Peserta didik yang memiliki AQ yang tinggi akan mempunyai sifat tidak mudah menyerah dalam menghadapi kesulitan, hal ini dapat membantunya ketika menghadapi masalah dalam pembelajaran.

Adapun faktor lain yang diduga dapat memberikan peran untuk mencapai prestasi belajar yang baik pada pembelajaran matematika yaitu kecerdasan emosional (emotional quotient) atau biasa 
disingkat dengan EQ. Goleman (2002) menjelaskan bahwa kecerdasan emosi adalah kemampuan untuk mengenali perasaan kita sendiri dan perasaan orang lain, kemampuan memotivasi diri sendiri, dan kemampuan mengolah emosi dengan baik pada diri sendiri dan dalam hubungan dengan orang lain. Sedangkan menurut Stein \& Book (2002) kecerdasan emosional adalah kemampuan untuk mengenali perasaaan, meraih dan membangkitkan perasaaan untuk membantu pikiran, memahami apa yang dirasakan dan memaknainya, dan mengendalikan perasaan tersebut secara mendalam sehingga dapat membantu untuk mengembangkan emosi dan intelektual.

Pada pembelajaran di kelas terutama dalam pembelajaran matematika peserta didik terkadang menghadapi masalah yang berkaitan dengan aktivitasnya di kelas, termasuk dalam memahami materi dan mengerjakan tugas yang diberikan. Sebagai contoh, tidak jarang peserta didik mengeluhkan: saya tidak memiliki semangat belajar, saya tidak paham dengan materi yang dijelaskan dan sebagainya yang mengakibatkan peserta didik sulit untuk berkembang. Ini merupakan pengaruh dari aspek emosional peserta didik yang kurang dapat dikontrol oleh peserta didik. Maka dari itu sebagai seorang pendidik, guru haruslah dapat mengendalikan dan memaksimalkan kecerdasan emosional peserta didik dalam kegiatan pembelajaran di kelas untuk membantu peserta didik mengembangkan ilmu pengetahuan yang dimiliki peserta didik dan meraih prestasi belajar yang lebih maksimal.

Hasil penelitian yang dipaparkan oleh Purnama (2016) menunjukkan bahwa kecerdasan emosional memiliki pengaruh yang signifikan terhadap prestasi belajar peserta didik. Peserta didik yang memiliki kecerdasan emosional yang baik dapat mengontrol emosi-emosi yang dirasakan, mengendalikan emosi-emosi negatif yang dapat menghambat proses pembelajarannya di kelas agar dapat membantunya untuk meraih hasil belajar yang lebih baik. Hasil penelitian tersebut juga sejalan dengan penelitian yang dilakukan oleh Setyawan \& Simbolon (2018) yang menunjukkan bahwa kecerdasan emosional memberikan dampak terhadap meningkatnya hasil belajar matematika peserta didik. Pada hasil penelitiannya membahas bahwa dalam menyelesaikan masalah pada mata pelajaran matematika diperlukan konsentrasi, kesabaranm dan ketelitian yang baik. Dalam mengelolah hal tersebut dibutuhkan pengelolaan kecerdasan emosional yang kuat, sehingga peserta didik tidak mudah putus asa dan menyerah ketika belum menemukan jawaban yang tepat.

Penelitian ini bertujuan untuk menganalisis adversity quotient, emotional quotient dan prestasi belajar matematika yang dimiliki oleh peserta didik dan untuk mengetahui ada atau tidaknya pengaruh dari adversity quotient dan emotional quotient terhadap prestasi belajar matematika peserta didik.

\section{METODE PENELITIAN}

Jenis penelitian yang digunakan dalam penelitian ini adalah penelitian kuantitatif dengan metode penilitian yaitu penelitian ex-post facto. Pada penelitian ini terdapat variabel emotional quotient $\left(\mathrm{X}_{1}\right)$ dan adversity quotient $\left(\mathrm{X}_{2}\right)$ yang merupakan variabel-variabel bebas dan variabel prestasi belajar matematika (Y) yang merupakan variabel terikat atau variabel yang dipengaruhi.

Model persamaan struktural dari desain penelitian menurut Gambar 1 adalah sebagai berikut:

$$
Y=\beta_{y 1} x_{1}+\beta_{y 2} x_{2}++\varepsilon_{1} \ldots \text { (i) }
$$

Keterangan :

$\mathrm{X}_{1} \quad=$ Emotional Quotient $(\mathrm{EQ})$

$\mathrm{X}_{2} \quad=$ Adversity Quotient (AQ)

$\mathrm{Y}=$ Prestasi Belajar matematika 
$\varepsilon_{1}=$ Eror/Variabel Residu 1

$\beta_{y 1} \quad=$ Koefisien Jalur $\mathrm{X}_{1}$ Terhadap $\mathrm{Y}$

$\beta_{y 2}=$ Koefisien Jalur $\mathrm{X}_{2}$ Terhadap $\mathrm{Y}$

Adapun desain penelitan ini adalah sebagai berikut:

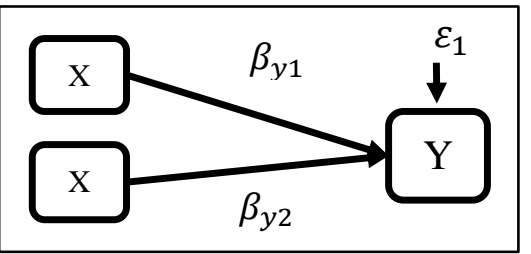

GAMBAR 1. Desain Penelitian dengan Menggunakan Analisis Jalur

Penelitian ini dilakukan pada semester Ganjil tahun ajaran 2019/2020 di SMA. Sampel pada penelitian ini diambil dengan menggunakan teknik pengambilan sampel yaitu cluster proportional random sampling. Pengambilan sampel ini dilakukan dengan mengambil anggota populasi secara acak. Adapun jumlah sampel pada penelitian ini yaitu 158 peserta didik.

Pengumpulan data pada penelitian ini dilakukan dengan teknik pemberian tes dan non tes. Adapun instumen yang digunakan dalam penelitian ini ada 3 yaitu, angket emotional quotient, angket Adversity Response Profile (ARP) dan tes prestasi belajar matematika. Semua instrumen yang digunakan telah divalidasi. .

Data yang diperoleh selanjutnya dianalisis dengan menggunakan teknik analisis data yang mencakup analisis statistik deskriptif dan analisis statistik inferensial. Dalam penelitian ini, analisis statistik deskriptif digunakan untuk mendeskripsikan setiap variabel penelitian sedangkan analisis statistik inferensial digunakan untuk menguji hipotesis penelitian. Metode analisis yang digunakan dalam penelitian ini adalah analisis kuantitatif dengan analisis regresi linear berganda pada taraf kepercayaan $95 \%(\alpha=0,05)$. Sebelum melakukan analisis regresi perlu terlebih dahulu dilakukan uji asumsi/prasyarat yang meliputi uji autokorelasi, multikolinearitas dan heteroskedastisitas. Adapun hipotesis statistik yang akan diuji adalah sebagai berikut:

1. Hipotesis 1: $H_{0}: \beta_{Y 1}=0$ lawan $H_{1}: \beta_{Y 1}>0$

$H_{0}$ : Tidak ada pengaruh positif Emotional Quotient (EQ) terhadap prestasi belajar matematika peserta didik

$H_{1}$ : Ada pengaruh positif Emotional Quotient (EQ) terhadap prestasi belajar matematika peserta didik

2. Hipotesis 2: $H_{0}: \beta_{Y 2}=0$ lawan $H_{1}: \beta_{Y 2}>0$

$H_{0}$ : Tidak ada pengaruh positif Adversity Quotient (AQ) terhadap prestasi belajar matematika peserta didik

$H_{1}$ : Ada pengaruh positif Adversity Quotient (AQ) terhadap prestasi belajar matematika peserta didik

\section{HASIL ANALISIS DATA DAN PEMBAHASAN}

\section{Hasil Analisis Statitik Deskriptif}

\section{Prestasi Belajar}

Rata-rata nilai prestasi belajar matematika peserta didik sebesar 44,3044 sehingga secara umum prestasi belajar matematika peserta didik berada pada kategori rendah. Hal ini menunjukkan bahwa mayoritas peserta didik masih belum sepenuhnya paham dengan materi matematika yang 
diajarkan, sehingga pendidik harus lebih memperhatikan proses belajar peserta didik agar prestasi belajarnya dapat ditingkatkan.

TABEL 1. Distribusi Frekuensi dan Persentase Skor Prestasi Belajar Matematika

\begin{tabular}{cccc}
\hline Interval Nilai & Kategori & Frekuensi & Persentase (\%) \\
\hline $0-34$ & Sangat Rendah & 62 & $39,24 \%$ \\
$35-54$ & Rendah & 46 & $29,11 \%$ \\
$55-74$ & Sedang & 19 & $12,03 \%$ \\
$75-84$ & Tinggi & 23 & $14,56 \%$ \\
$85-100$ & Sangat Tinggi & 8 & $5,06 \%$ \\
\hline \multicolumn{5}{c}{ Jumlah } & \multicolumn{1}{c}{$\mathbf{1 6 4}$} & $\mathbf{1 5 8}$ \\
\hline TABEL 2. Distribusi Frekuensi dan Persentase Skor Emotional Quotient \\
\hline Interval Nilai & Kategori & Frekuensi & Persentase (\%) \\
\hline skor $\leq 96,16288$ & Sangat Rendah & 10 & $6.33 \%$ \\
$96,16288<$ skor $\leq 107,48879$ & Rendah & 39 & $24,68 \%$ \\
$107,48879<$ skor $\leq 118,8147$ & Sedang & 63 & $39,87 \%$ \\
$118,8147<$ skor $\leq 130,14061$ & Tinggi & 35 & $22,15 \%$ \\
$130,14061<$ skor & Sangat Tinggi & 11 & $6,96 \%$ \\
\hline \multicolumn{5}{c}{ Jumlah } & & $\mathbf{1 5 8}$ & $\mathbf{1 0 0}$ \\
\hline
\end{tabular}

Rata-rata emotional quotient peserta didik yaitu sebesar 112,9406 yang menunjukkan bahwa secara umum emotional quotient berada dalam kategori sedang. Hal ini menunjukkan bahwa peserta didik masih perlu untuk belajar dalam mengendalikan emosi-emosi yang dirasakannya pada saat proses pembelajaran matematika berlangsung.

TABEL 3. Distribusi Frekuensi dan Persentase Skor Adversity Quotient

\begin{tabular}{cccc}
\hline Interval Nilai & Kategori & Frekuensi & Persentase (\%) \\
\hline $0 \leq$ skor $<60$ & Quitter & 0 & $0 \%$ \\
$60 \leq$ skor $<95$ & & 4 & $2.53 \%$ \\
$95 \leq$ skor $<134$ & Camper & 98 & $62,03 \%$ \\
$134 \leq$ skor $<166$ & & 53 & $33,54 \%$ \\
$166 \leq$ skor $\leq 200$ & Climber & 3 & $1,90 \%$ \\
\hline Jumlah & & $\mathbf{1 5 8}$ & $\mathbf{1 0 0}$ \\
\hline
\end{tabular}

Rata-rata adversity quotient peserta didik yaitu sebesar 128,4747 sehingga secara umum adversity quotient berada dalam kategori camper. Hal ini menunjukkan bahwa peserta didik akan berusaha dalam menyelesaikan permasalahan matematika yang di hadapinya tetapi tidak menggunakan seluruh kemampuan yang dimilikinya, dalam mengerjakan soal matematika mereka tidak akan mengambil resiko yang terlalu besar untuk mencari jawaban lain ataupun cara kerja lain dari jawaban yang diperolehnya dan terkadang mereka merasa sangat cepat puas dengan hasil yang telah diperolehnya.

\section{Hasil Analisis Statistik Inferensial}

Uji Prasyarat

a. Uji Multikolenieritas

TABEL 4. Hasil Uji Multikoleniaritas

\begin{tabular}{cccc}
\hline Variabel & Tolerance & VIF & Keterangan \\
\hline Emotional Quotient & 0,948 & 1,055 & Tidak terjadi \\
Adversity Quotient & 0,927 & 1,078 & multikoleniaritas \\
\hline
\end{tabular}


Tabel 4 menunjukkan bahwa nilai Tolerance setiap variabel lebih besar dari 0,1 dan nilai VIP untuk setiap variabel pada masing-masing model lebih kecil dari 10, sehingga antar variabel bebas tidak terjadi gejala multikoleniaritas.

b. Uji Autokorelasi

Hasil uji autokorelasi diperoleh bahwa nilai DW $=1,828$ pada taraf signifikan $5 \%$ dengan jumlah sampel $158(\mathrm{n}=158)$ dan jumlah variabel independen $2(\mathrm{~K}=2)$ maka $\mathrm{dL}=1,7014$ dan $\mathrm{dU}=1,7787$, Karena DW berada pada $\mathrm{dU}<\mathrm{DW}<4$ - dU yaitu $1,7787<1,828<2,2213$. maka dapat disimpulkan bahwa tidak ada autokorelasi positif maupun negatif pada variabel emotional quotient, adversity quotient dan kemampuan pemecahan masalah matematika terhadap prestasi belajar matematika.

c. Uji Heteroskedastisitas

TABEL 5. Hasil Uji Heteroskedastisitas

\begin{tabular}{ccc}
\hline Variabel & Significancy & Keterangan \\
\hline Emotional Quotient & 0.118 & Tidak terjadi \\
Adversity Quotient & 0.234 & heteroskedastisitas
\end{tabular}

Dengan melihat nilai signifikan dan alpha $=5 \%$. Terlihat bahwa nilai sig >alpha untuk semua variabel independen yang artinya tidak ada satupun variabel independen yang signifikan secara statistik mempengaruhi variabel dependen. Jadi dapat disimpulkan bahwa model regresi tidak mengandung adanya Heteroskedastisitas.

Pengujian Hipotesis

TABEL 6. Hasil Uji Substruktural

\begin{tabular}{ccccccc}
\hline $\begin{array}{c}\text { Variabel } \\
\text { Independen }\end{array}$ & $\begin{array}{c}\text { Standarized } \\
\text { Coefficient beta }\end{array}$ & $\mathbf{T}$ & $\begin{array}{c}\text { Sig. } \\
\text { Coefficient }\end{array}$ & $\boldsymbol{R}^{\mathbf{2}}$ & $\boldsymbol{F}$ & Sig. Anova \\
\hline$X_{1}$ & 0.216 & 2.776 & 0.006 & 0,112 & 6.498 & 0.000 \\
$X_{2}$ & 0.152 & 1.925 & 0.056 & & & \\
\hline
\end{tabular}

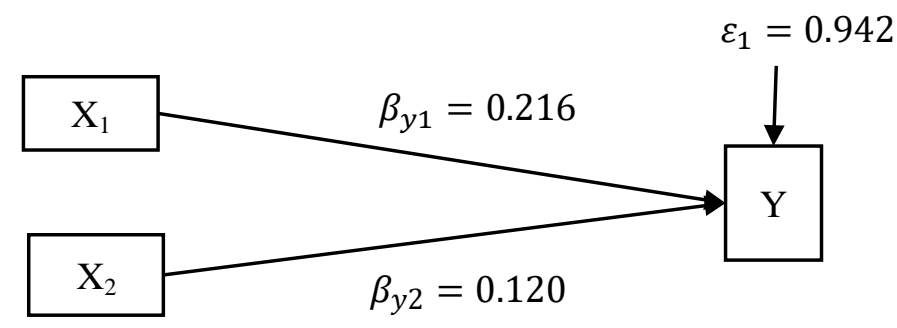

GAMBAR 2 Desain Analisis t - uji substural

Berdasarkan hasil analisis regresi terhadap masing-masing substuktural diperoleh:

$Y=0,216 X_{1}+0,152 X_{2}+0.942$

a. Pengujian hipotesis 1

Emotional Quotient (EQ) berpengaruh secara positif terhadap prestasi belajar matematika peserta didik.

$$
H_{0}: \beta_{Y 1}=0 \text { lawan } H_{1}: \beta_{Y 1}>0
$$


Berdasarkan tabel $6 \mathrm{X}_{1}$ memiliki nilai signifikan sebesar 0,006 yang lebih kecil dari 0,05 sehingga $H_{0}$ ditolak. Berdasarkan hasil analisis diperoleh nilai $\beta_{Y 1}>0$ yaitu 0,216 artinya $H_{1}$ diterima. Dengan demikian, variabel $E Q$ berpengaruh positif terhadap prestasi belajar matematika peserta didik

b. Pengujian Hipotesis 2

Adversity Quotient $(A Q)$ berpengaruh positif terhadap prestasi belajar matematika peserta didik.

$$
H_{0}: \beta_{Y 2}=0 \text { lawan } H_{1}: \beta_{Y 2}>0
$$

Berdasarkan tabel $6 \mathrm{X}_{2}$ memiliki nilai signifikan sebesar 0,056 yang lebih besar dari 0,05 sehingga $\mathrm{H}_{0}$ diterima. Berdasarkan hasil analisis diperoleh nilai $\beta_{Y 2}=0$. Dengan demikian, variabel $A Q$ tidak memiliki pengaruh positif terhadap prestasi belajar matematika peserta didik.

\section{Pembahasan}

Variabel emotional quotient (EQ) memberikan pengaruh langsung yang positif terhadap prestasi belajar matematika peserta didik. Namun, pengembangan EQ peserta didik masih terlihat kurang, hal ini dapat dilihat dari data tingkat EQ peserta didik yang berada pada kategori sedang. Hal ini tentunya perlu untuk lebih diperhatikan oleh para pendidik karena EQ ternyata memiliki pengaruh terhadap prestasi belajar matematika, agar kedepannya prestasi belajar peserta didik yang tergolong pada kategori rendah bisa lebih ditingkatkan lagi.

Variabel adversity quotient (AQ) tidak memberikan pengaruh langsung terhadap prestasi belajar matematika peserta didik. Tidak adanya pengaruh AQ diduga karena peserta didik masih kesulitan dalam menghadapi masalah yang dihadapinya saat pembelajaran di kelas. Hal ini dapat dilihat dari data analisis deskriptif pada angket AQ peserta didik yang memiliki tingkat AQ pada kategori camper yang mana sesuai ungkapan Stolz (2002) peserta didik yang berada pada ketegori camper menunjukkan peserta didik masih cenderung cepat puas pada hasil belajar yang dicapainya, tidak berusaha semaksimal mungkin agar bisa meraih hasil yang lebih baik lagi, apapun hasil yang diperolehnya mereka akan menerima hasil tersebut. Sehingga peserta didik akan sangat sulit untuk berkembang dalam proses pembelajaran ataupun pada hasil belajarnya.

\section{KESIMPULAN}

Adversity quotient dan emotional quotient peserta didik berdasarkan nilai rata-ratanya berada pada kategaori sedang, sedangkan prestasi belajar peserta didik berdasarkan nilai rata-ratanya berada pada kategori rendah.

Emotional quotient berpengaruh signifikan dan positif secara langsung terhadap prestasi belajar matematika peserta didik sedangkan adversity quotient tidak berpengaruh signifikan terhadap prestasi belajar peserta didik.

\section{DAFTAR PUSTAKA}

Adiputra, S., \& Mujiati., (2017). Motivasi dan Prestasi Belajar Peserta didik di Indonesia: Kajian Meta-Analisis. KONSELIR.

Akbar, R. \& Hawadi. (2004). Akselerasi: A-Z program percepatan belajar dan anak berbakat intelektual. Jakarta: Grasindo.

Goleman, D., (2002). Kecerdasan Emosional. Terjemahan. Jakarta: Gramedia Purtaka Utama. 
Leonard., \& Amanah, N., (2014). Pengaruh Adversity Quotient (AQ) dan Kemampuan Berpikir Kritis Terhadap Prestasi Belajar Matematika. Jurnal Perpektif Ilmu Pendidikan. 28(4), 54-63.

Nurhayati, \& Fajrianti, N., (2013). Pengaruh Adversity Quotient (AQ) dan Motivasi Berprestasi Terhadap Prestasi Belajar Matematika. Jurnal Formatif. 3(1), 72-77.

Purnama, I., M., (2016). Pengaruh Kecerdasan Emosional dan Minat Belajar Terhadap Prestasi Belajar Matematika Di SMAN Jakarta Selatan. Jurnal Formatif, 3(6). 233-245.

Setyawan, A., A., \& Simbolon, D., (2018). Pengaruh Kecerdasan emosional terhadap prestasi belajar matematika siswa smk kansai pekanbaru. JJPM. 11(1), 11-18.

Stein, S.J \& Book, H.E. (2002). LEDAKAN EQ: 15 PRINSIP DASAR KECERDASAN EMOSIONAL MERAIH SUKSES. Bandung: Penerbit Kaifa.

Stolz, P.G. (2000). Adversity Quotient, Mengubah Hambatan menjadi peluang. Terjemahan. Jakarta: PT Gramedia Widiasarana Indonesia.

Supardi, U.S., (2013). Pengaruh Adversity quotient Terhadap Prestasi Belajar Matematika. Jurnal Formatif. 3(1), 61-71. 